\title{
JOTTINGS FROM A YEAR BOOK EDITOR'S NOTE BOOK
}

\author{
WILLIAM C. BoLLAND
}

It would be no gross exaggeration to say that the earlier Year Books are themselves in the main of the character of expanded note-books of memoranda made at the time of the salient points of cases heard in the mediæval courts, of the pleas advanced therein successfully or unsuccessfully, and of the ratings and judgment of the Justices. But besides this, their primary purpose, they abound in detached items of interesting information about matters which have little or nothing to do with the reporters' immediate business, but which may, if he can recollect them at the right moment, be very helpful to a student who is trying to re-construct the procedure of the early courts and to re-create the atmosphere, political and social, as well as legal, in which the earlier Justices lived and worked. As there are many manuscripts dealing with the same terms and years, these, necessarily, cannot all be printed in full; and, consequently, many little notes of interest, the future practical use of which to the lawyer, the legal, social or general historian cannot be foreseen, must perforce be omitted from any possible edition of the Year Books. But such things an editor jots down in his note-book, to be of use when and if the occasion does arrive. And not infrequently, it may be years after the note was made, the opportunity for its profitable use comes, and one rejoices that the note has been made. But of many of such notes I have as yet had no opportunity of making any practical use, and quite possibly never may have. It has occurred to me that some of these may be useful to students busying themselves with the study of those subjects with which I myself have been mainly concerned and who have not had the same opportunities of consulting original sources as have happily been possible for myself. To such I hope that they may at least be of interest, even if of no practical use, . and that a few pages of this Journal may be, not altogether unprofitably, given up to some jottings from $\mathrm{my}$ note-books and some reflections and comments thereon. I have not, I am afraid, kept my note-books in any very methodical manner. Notes on all sorts of widely different matters follow each other in haphazard fashion, just as they were jotted down in the course of my studies in this place or that, different notes on the same subject or related subjects being widely separated from each other. For the purposes of this paper I must necessarily do some little co-ordination and collation, that I may not be too incoherent. Still, as the note- 
books are inconsequential, I am afraid that this paper must also in some degree partake of the note-book's nature.

As one must begin somewhere, perhaps I cannot make a better beginning than with a note or two I find on the Year Books themselves-the generally accepted theory, a theory which I certainly hold myself, is, I think, that they were the work of reporters stationed in a box known as "the crib," situated conveniently near the bench. But these reporters seem to have had opportunities and advantages which could scarcely have been open to reporters who merely kept their ears open in a box which was, at any rate, some distance away from the bench on which the Justices were sitting. These mediaeval Justices, like their modern successors, occasionally put their heads together and held a whispered consultation. In one report we read that Bereford, C. J., withdrew with two other Justices and said certain things to them; but the reporter is able to tell us what it was that Bereford said. In another case, heard about the same time, Redenhale, one of the clerks of the court, explained in secreto what the rule usually followed in certain matters was. Somehow or other the reporters are able to tell us what Redenhale thus said in secreto. One more instance, which I will take from a report made many years later, I quote because while being an apposite example it is also interesting as containing an expression of which I know no other instance, at the meaning of which one can only guess. In 33 Henry VI an action of trespass was brought for the illegal detention of a box and its contents. The defendant pleaded that there was nothing tortious in his possession of the box. He had found it lying in the road-Littleton then said "secrettement qe cest declaracion per inventionem est un new found Haliday". Here we have again something that was said secrettement retailed to us by the reporters. What was " $a$ new found Haliday", or Holiday? The fact that the words are given in English and not in the usual Anglo-Norman of the reports justifies us, I think, in supposing that it was a proverbial expression in general use at the time to express something or other. I cannot find it in any of the old dictionaries or glossaries and so I am driven to suggest a probable meaning for it myself; and the most plausible interpretation which occurs to me is that Littleton meant to say that such a defence to an action for trespass was a newly invented fad. But that is by the way. The real point of what I have been saying is that the reporters in their crib were somehow enabled to give us observations made privately or secretly by Justices and Sergeants. And in their zealous quest for reportable matter they seem sometimes to have tacked themselves on to the Justices as they were going home from the courts. I do not know how else they come to tell us of certain things which 
the Justices said veniendo de W'stimizstei about cases which they had been trying.

Of other matters, too, these old reporters tell us, matters of which they certainly did not hear in their official crib. The writs issued from the Chancery, and were drafted there by the Chancery clerks; and these clerks seem to have developed a somewhat exaggerated idea of their orm omniseience and infallibility as to the wording of the writs draited by them, strongly resenting any outside interference or attempt at correction-even though these came from a Chief Justice. Beritford had quashed a certain writ on the ground, shortly, that it disclosed no right of action. The plaintiff appears to have been very angry and to have gone off to the Chaneery to complain about such a worthless writ having been sold to him. The eleiks were not going to admit that they were in the wirong; and they sent of a peremptory summons to Bereford, the Chief Justice of the Common Bench, to wait on them at the Chancery and explain his reasons for quashing the wit which they had issued. And, what is perhaps more wonderful still, when we remember Eereford's natural temperament, he did go and did explain for what reasons he had quashed the writ. Did the reporters go with him, or in what other way did they come to know what happened? I wish they had been a little fuller in their account of Bereford's visit to the Chancery, for I think that a verbatim report of the Chief Justice's remarks in the rernacular when he got there would not be without its interest. A couple of these elerlis of the Chancery were in the great Hall of Westminster in January, 1322, at a time when the Iring himself was present $i_{i l}$ camera, together with the prelates and magnates of the realm; and they began to quarrel together about something, whether about the wording of a writ or what, I do not lnow, but at any rate one of them killed the other, and he himself, an old ehronicle tells us, was immediately hanged. Violence of this lind always met with very speedy punishment if it occurred within the immediate neighborhood of the King.

There are some unprinted manuscripts of Eyre Year Bools in the Library of Lincoln's Inn which would well repay editing and publishing, for they abound in interesting matter. I have many notes on their contents, dealing with one subject and another, some of which I will reproduce here. There is, amongst them, a rather strange case, giving us a very early example of the doctrine of scienter. It is from the reports of the Eyre of Northamptonshire of 3 Edward III. A vicious horse attaclied a child and inflicted such injuries on it that it died a couple of days later. When, a long time afterwards, the circumstances were reported to the Justices of the Eyre and inquired into by them, by which time the owner of the horse was dead, the court asked 
if the horse was a vicious one and if its owner knew that it was vicious. Both questions were answered in the affirmative. Then, said the court, if the owner were now alive he would have been arraigned for the death of the child, for a duty was cast upon him to keep such an animal in some secure place, the inference being that then, as now, the owner of a domestic animal, such as a dog or a horse, must be shown to have had reasonable cause for being aware of its vice before he can be punished for such consequences as arise from it.

A certain man was hanged for felony. When he was "cut down" he revived, took sanctuary in a church and went through the ceremony of abjuration. The circumstances were reported in Eyre; and the court ruled that the abjuration was null and void, and they found also that the revivication amounted to an escape, for which the township was fined, for it ought, through its officials, to have seen that the sentence was properly executed. The position of the felon remained a somewhat peculiar one, as I read the observations of the court. The man, it was said, could only be hanged once, for by the first judgment he was put hors de la ley, and so judgment could not be passed upon him a second time. But, surely, if the first hanging was no hanging at all, but merely the first episode in an escape, he could have been arrested and hanged effectually, just as he could have been if he had escaped on the way to the gallows. We can hardly suppose that in those days the sheriff immediately signed a certificate that a judgment of death had been duly executed upon him, which he could have pleaded against any further proposed execution. The abjuration had been ruled to be bad and not to have had the effect of an abjuration, and so the man, if he had been found at large, could not have been summarily beheaded or subjected to any other form of rough and ready slaughter, as having left the direct way to the port from which he had received orders to leave the realm. Personally, I am in agreement with what, the report tells us, ascuns gents, which I suppose means some of the lawyers in court, said, that the man might have been arrested and hanged when he left the church, as the abjuration was of no effect, but they were of opinion that he could not have been turned out of the church before he voluntarily left it. Beheading seems to have been no uncommon end for felons who, having abjured the realm, left the direct road to the coast and tried to cover their tracks by slipping off into the country wilds. But there were many other summary and somewhat irregular beheadings in those days. Here is a note of one from our Northamptonshire Year Books. In 7 Edward II one Walter of Daventry happened to meet a certain John, and, quarreling with him, gave him such a deep stab with a knife under the left shoulder that John died a few days afterwards. Walter absconded, naturally. After an inquest, the 
sheriff and the coroner found Walter guilty of John's death; but, as Walter had disappeared, nothing further could then be done. After a time, I should imagine a considerable time, in view of the dates mentioned, Walter returned to his father's house, and then the local constables and town officials set out to arrest him. Walter seized a sword and ran away, threatening his pursuers, who followed him closely and called upon him to surrender to the King's peace. Walter refused, and thereupon one of his pursuers suddenly rushed up to him, and, in the short sharp words of the report, cut off his head. Let us consider dates for a moment. John was murdered by Walter in 7 Edward II. In the Eyre of 3 Edward III, sixteen years afterwards, the story is told in court in answer to one of the Articles of the Eyre, which called for a return of all felonies, homicides and robberies committed since the last Eyre, the exact date of which I have not been able to trace-but it was certainly a good many years before 3 Edward III. These enormous delays, caused by the long intervals between Eyres, intervals which were never less than of seven years' duration, a space long enough to have allowed offenders and witnesses to have died or disappeared, must have led to frequent failures of justice. But the Eyres, infrequent as they were, were so hated by the people at large, that they would willingly have seen the interval between successive ones twice or three times as long as it was.

Here is a note from the same book which seems to show that sometimes a strict application of the law may bring about a rather comical position. A. met on the road two robbers who attacked him. One of the robbers killed the traveller, who, however, before he succumbed, was able to deal that particular robber a blow which killed him. A felon's chattels, when he had any, which was not always, were forfeited to the king; and so in the case of every conviction for felony of any kind, an inquiry was held as to the chattels of which a felon had died in possession. Now our robber had not run away to avoid arrest. Naturally he could not, lying dead on the road. So it could not be held that he had practically confessed his guilt by absconding. And he had certainly not been convicted in court of the murder of the traveller. Consequently, the chattels of one who was undoubtedly a robber in intention and a murderer in fact were ruled to be immune from forfeiture. The King probably suffered no great loss. But the workings of the law in those days were sometimes iniquitous. Here is a story from the Nottinghamshire Eyre of 4 Edward III. It was the law in those days that confessedly stolen property which had been abandoned by the thief and afterwards recovered either by the owner or the local officers could not be, in the one case retained by the owner, or, in the other, returned to him until the thief had been prosecuted to conviction. The Eyre Book tells us of a thief who stole 
and drove off from the owner's land a flock of thirty sheep. The owner happened to come up immediately afterwards and saw .what had happened. He and some of his men pursued the thief, who, finding that he could not escape being captured if he stayed where he was with the sheep, ran off and took sanctuary in the nearest church, where he was safe from arrest and became entitled to abjure the realm and so escape prosecution. The sheriff in this case allowed the owner of the sheep, who had driven them home again, to retain possession of them. It seemed a very natural thing to do. But the sheriff, unhappily for himself, did not know the law. When the Eyre come round with its inevitable inquiries all the facts had to be disclosed. The Chief Justice of the Eyre was angry at such a breach of the law, to the King's detriment. The sheep, by being first stolen and then abandoned by the thief, had become the King's property, as the thief had not been prosecuted to conviction-and how could he have been? -and the sheriff would be held responsible for seeing that the King got the sheep or their value. Here again we have one of those rare notes of comment or criticism in which the reporters occasionally allow themselves to give expression to their own feelings and opinions. "A strange thing it seems," this particular" reporter wrote, "that the owner was not to have his sheep back, for no shadow of fault could be found in him". But where the King's interests were concerned and there was any chance of putting money into his coffers, the mediæval Justices were careful to exact all that strict law would enable them to exact. The King's advantage came before all equities. In this same Eyre a Prior wanted to take proceedings by bill which he could more properly have taken by writ. A bill cost nothing. In a writ issuing out of the Chancery a fee had to be paid to the King. The court refused to allow him to proceed by bill unless he paid the King what he would have had to pay him if he had got a writ from the Chancery.

Here is a note on an interesting case drawing the line between criminal manslaughter and excusable homicide. A man was charged with killing another. He pleaded that he had done so se defendendo. It was asked whether the man who was killed had broken into the other man's house for the purpose of robbery; for in such case the court held that not even a plea of se defendendo was necessary for the exculpation of the defendant. The jury found that the householder had not in fact killed the robber se defendendo; and therefore the court was not able to order, as it otherwise could have done, his immediate discharge, but said that he must stay in prison until he had received the King's formal pardon, which was apparently considered a matter of course in the circumstances. The actual facts, so far as they are ascertainable from the short report, seem to be these. A man 
finds another on his premises presumably for the purpose of robbery. He kills him, more or less "at sight", and certainly not se defendendo; yet he is practically acquitted. The doctrine of excusable or justifiable homicide has been very considerably modified since 3 Edward IV.

In the same Eyre a man and his wife sued jointly by a simple bill for a trespass done to both of them. The court quashed the bill on the following grounds. Damages were being sought, and it was held that although a husband might have damages for a trespass done to his wife, a wife could not have damages for a trespass done to her husband, as in this joint bill she was formally asking for. There ought to have been two bills, the court said, one by the husband for his own damages, the other by the husband and the wife for the wife's damages. A wife was in those days not much more than her husband's chattel. She could not sue without him, and any civil rights one had were practically vested in her husband during the coverture.

Here is an interesting example of the distinction between a judge's private knowledge and his official lmowledge, knowledge of which he might take judicial cognizance. On the last day of this Northamptonshire Eyre, William de St. Mans, a previous sheriff of the county, came before the court, and said that he was charged with allowing the escape of a prisoner in his official custody. He prayed the court for his discharge, for he had, he said, made formal delivery of that prisoner in the presence of the King to Sir Geoffrey Scrope, who was the Chief Justice of the Eyre, at Northampton, in the late Parliament holden in Northampton, a few weeks after Easter in the second year of Edward III. Scrope said that he remembered the circumstances very well, but, he added, "I cannot have cognizance of them as a judge; and as this Eyre is on the point of rising, and my commission, consequently, of expiring, I shall not after today have any authority to send for the official record of what happened. You must petition the King for the production in the King's Bench of the record of what happened, and in that record you will find the facts recorded. In that way you will get your discharge, but you cannot have it in any other way."

When a prisoner refused to plead it is common lnowledge that he was subjected to what was called peine foit $c t d u r c$, that is, he was taken to a dungeon, bare of all furniture, and there, having been stripped to his shirt, was to have as great a weight of iron laid upon his as he could bear without being at once crushed to death; to have, one day, a piece of bread to eat, and on another a drink from the nearest stagnant pool of water and so continue until he died. After such a sentence was pronounced and the unhappy wretch on whom it was pronounced was taken away to suffer it, we usually hear no more of him. But from a note 
in our Eyre Year Book it seems not unlikely that an inquest was sometimes held on his body after his death. Here is an instance, the only one I know, where some sort of informal inquiry was certainly held. There may have been, of course, perhaps were, suggestions that the man's death had been expedited in repelling his own violent behavior. The note tells us that a certain man died "in his penance", and the Justices commanded the coroner to go and inquire whether he died of the natural consequences of his penance or of a wound or any other cause. The coroner went in accordance with his instructions, and, without holding a for. mal inquest-sanz inqueste prendre-made his report to the Justices-we are not told what the report was-and the Justices thereupon ordered that the man's body should be buried.

In the Derbyshire Eyre of 4 Edward III, one man fiercely attacked another, for which he was arrested and then liberated on mainprise, and immediately absconded. The wounded man lived for five days and then died of his injuries. When the Eyre came round of course all the circumstances were reported to the court, which at first was inclined to make the township responsible for the escape, and to amerce it therefor. The township, however, pleaded through its representatives, that the wounded man had survived for full five days, that they did not feel justified in hanging their prisoner while the other man still lived, neither did they think that they were bound to keep him a close prisoner during that time, and so they had released him on what seemed sufficient security for his appearance. The court, having considered these representations, came to the conclusion that this was not a case of "escape" for which the township should be held responsible, "for, seeing that the man had lived so long a time, they hoped that he would recover". I think that the township was extremely lucky.

Here is an example of a quibbling defence of which the court made short work. One Alice claimed on a bond thirty stones of wool. The obligee had bound himself to deliver to her a sack of wool ; and it was contended that a claim for thirty stones of wool could not be supported by a promise to deliver a sack of wool. "If", said Chief Justice Hale, "I claim nine marks from you, and in support of my claim I produce your bond for six pounds, do you suppose that I shall not get a hearing?"

Questions of responsibility for the consequences of alleged improper medical or surgical treatment must have been more difficult to deal with in those times, with their absence of recognized licensing medical authorities, than they are today when the possession of a recognized qualification to practice is a good defence to almost everything except provable negligence. One of our Eyre Books of 4 Edward III tells us how a certain person complained that the defendant had undertaken to cure his eye "with 
oils and other medicines", but the only result of the trestment was that his eye was so injured that he lost it, and he brought his bill for trespass. It was pleaded in defence that here was no ground for suing in trespass; the plaintiff had gone to the defendant and had put himself voluntarily under his treatment. If he had any ground of action at all it would be by way of a writ for breach of covenant. Then Denham, J., said: "There was a man arraigned before me and my companions at Neweastle for homicide. I asked for the particular circurnstances, and I was told that he had bled a man who was under his care so severely that he died within the next four days. And because I say that the defendant was a man who was expert in his eraft (de ticl mestrie), and that the patient's death was not caused feloniously but, indeed, came about much to the defendant's regret, I discharged him. And I put the case to you, that a farrier who is expert in his craft happens by mischance to drive a nail into your horse's hoof, with the result that you lose it. In such a case you will never recover damages against him. Neither will you in this case." But against this see Fitzherbert's Notzl'o Brevivm, 94D. "If a smith prick my horse with a nail, ete. I shall have my action upon the case against him, without any warranty by the smith to do it well. For it is the duty of every artificer to exercise his art rightly and truly as he ought." And see, too, a case reported in the Year Boolss of the Trinity Term of $46 \mathrm{Edward}$ III (p. 19) case 19, where a wit which clained damages ran quare clavem fivit in pede equi sui in certo loco pei quod proficuum aqui sui per longum tempus amisit was ruled to be good.

Here is a note of a case which the report tells us gave the Justices much cause for thought and careful considerationceste chose demora longement en avisemont devant les Justices. One of two men killed another man, and the other of the two stoned the murdered man after he was dead. The question which, so far as I understand the report, the Justices propounded to themselves was this. Did this blow do anything to expedite the man's death or destroy any possibility of his recovery? Eut as we are told that the man was dead it is difficult to see that the blow could have had any material effect at all. It is possible that I have not quite grasped the meaning of the words of the French original, which are these: demande fut si par cel coup fust plus prest le mort ou plus logins de la rie. The Justices, after their long avisement, finally delivered themselves of this judgment. Because the striker of the blow was actuated by malice and struck with malicious intention-puir cco qe la renzze de luy fust malveys qi le ferist par mal volunte-he must pay a ransom to the king; and because he was present when the man was murdered and he did not arrest the murderer-it pur cєo . 
qil feust en presence qant le homme feust occis et ne arestu point le feloun, he was in mercy, to what amount is not, which is quite usual, stated. The report is not very lucid. Either the man was dead or was not when the blow was struck. If he was, as we are told he was, there seems nothing to argue about. If he was not, and the final blow was actually the coup de grace, then something more than merely pecuniary penalties seem called for.

Here is an illustration of the eagerness of the Justices of the Eyre to gather in a little money, or much, as the case might be, on any excuse they could find. It was reported to them that the naked body of a man had been found in the fields belonging to a certain township, and that it had lain there so long that the crows and other birds had plucked out the dead man's eyes. That the body had not been discovered, however, was attributed to the township's negligence; and the township had to pay a corporate fine. We have an interesting declaration as to the King's authority personally to deliver a special judgment in special circumstances. In the Bedfordshire Eyre of 4 Edward III one Richard and his wife brought a writ of novel disseisin, complaining that they had been disseized, inter alia, of Bedford Castle. It was objected that there was no Castle at Bedford, that what the complainants described as such was besieged by Henry III in 1224, "and taken by force of war and his enemies therein were taken and adjudged to death; and at the same time it was adjudged that the Castle should be destroyed and lose its name". In answer to a challenge by the complainants' counsel to say where this judgment was made, in the Bench, in Parliament or where, it was answered that "the King, seated on his horse on the field of battle, has power to deliver such a judgment in time of war, and such a judgment shall be a matter of record forever". "A manor can be created at the will of him who creates it, but the King alone can grant the right to have a castle". And this statement of the common law was not controverted.

It is not unknown nowadays for a judge to complain of the bad or illegibly written depositions supplied to him; but I do not know that any modern judge has gone beyond complaining, and unless he could see his way to ruling that the submission of such badly written documents really amounts to a contempt of the court, I do not quite see what else he could do. But the medixval courts believed in and used sterner methods. In Plea Roll of the Common Bench of the Michælmas Term of 8 Edward II the court complained that the names of the pledges of a jury in default were so badly written-ita inaperte et indistincte that they could not be read with certainty-certe legi aut intelligi non poterunt; and it fined the offending sheriff forty shillings, a really considerable sum in those days, probably something like twenty times the present value of a like nominal sum. 